\title{
Care of the Dying
}

Under the auspices of the Department of Health and Social Security a symposium on the "Care of the Dying" was held at the Royal College of Physicians on 29 November 1972. Surgeon Rear-Admiral F. M. Holford took the chair in the absence of Sir George Godber. Below we print versions of the papers presented at the Symposium. These have been prepared from the speakers' original scripts or abstracts of their papers prepared from the transcript of the proceedings.

The Secretary of State, SirKeith foseph, welcomed members of the audience, and expressed the hope that, with so many different organizations represented, a useful and valuable exchange of ideas might improve standards of care of the dying.

\section{A Death in the Family: A Lay View}

\section{SHEILA HANCOCK}

When I was told that my mother had cancer and had about nine months to live, I had very little experience of any sort of illness and no first-hand experience of death whatsoever. It is extraordinary to reach my grand old age and have to admit that, but it was true. Therefore my first instinct was one of total panic, not necessarily because of my inexperience of death but because I felt that I would not be able to cope and that thereby I might increase my mother's suffering. The awful thing that I found was that there was nowhere that I could turn. What I did find again and again (and this is a generalization) was an attitude in the medical profession of appearing not to want to know about the incurably ill. Now I think there are lots of reasons for that. One is possibly because medical education is geared to cure; somebody dying therefore represents a failure and none of us likes to face failure. If I might give you an example. My husband's specialist was one day extra specially curt to my husband when he was feeling pretty feeble, and I asked his much more sympathetic assistant why he behaved like that. He said, "It is because he cares so much," and I said, "Well, he has an extraordinary way of showing it." "No" said the assistant, "he can't allow himself to become emotionally involved in your problems because he has to make clinical decisions; he has to operate on your husband and he has got to be quite cold in the operating room." Now I absolutely see that, but it doesn't help the patient.

I found the same thing with nurses, strangely enough. I saw nurses in ordinary hospitals sometimes being unbelievably insensitive to patients who were chronically ill, and I felt again it was partly their sense of failure. I did also think, on talking to them, that possibly their education had been slightly lacking in the psychological approach to dying people, and I thought there were two things that possibly could be improved in that direction: firstly, an improvement during their training of the psychological approach, or, secondly, possibly not expecting medical staff who have been geared to cure to have to cope with the dying-perhaps it should be a separate body of people.

\section{Facilities Available}

The other area in which I found a terrible lack of information was about the facilities that were available to me. I promise you that at no time during my mother's illness did anybody tell me that I was entitled to have district nurses. Maybe I slipped through lots of loopholes in some way but I found out by myself that I could. I did not know about the Red Cross and the things that they could supply. I did not know about the million and one things that are available. I did not even know, believe it or not, about the Marie Curie Foundation until after my mother had died. It seems to be that there is some deficiency here. One should be referred to people who can give you the information that can help you.

Having had no experience of illness I desperately wanted to learn how to take care of my mother and you do not, as an actress, know how to deal with bed sores and enemas and suppositories and things like that. But I found a strange resistance in some of the nurses to teach me; they seemed to think I was invading their professional privacy in some way. Some did not, so I am generalizing again, but there was this curious attitude-as with a lot of specialists-that it was not my business. They do not think it is the relative's business to know the mechanics of illness, but I do not think that anything I coped with with my mother and my husband was anything near as bad as the things I imagined from my ignorance. I would much rather have known the truth and been told what to expect, but they did not want to do that, a lot of them. 
As regards pain, as long as my mother was taking drugs orally that was all right-I could cope. But when it got to the stage that she could not keep anything down and we had to have injections it was terrifying a situation. I could not 'phone my G.P. at all hours of the night; there was no 24-hour service as far as I knew; and in fact I was often left in the middle of the night with my mother in absolute agony not knowing where to turn. I know now that there were places that could have helped me, but I did not at the time.

\section{Treatment at St. Christopher's Hospice}

Now after that tirade of criticism, which is obviously only about some aspects of it, may I say that in my husband's case everything was totally different. A month after my mother died I was told that my husband had cancer of the oesophagus and had about a year to live. I think possibly because of this, and it being the same hospital, they thought I needed a lot of help so I was referred to St. Christopher's Hospice. At first I regarded the idea with horror because I knew it was a terminal home and I hated the idea of my young husband being surrounded by dying people. I did not want him to know he was dying because, after a great deal of thought, I considered he was the sort of man who was probably better left in ignorance of that and I thought he would guess, being in this hospital. In fact (and this is very interesting) he never did. He gained nothing but inspiration and happiness from being in that hospital. He went in occasionally and then came home and I was helped at home.

The other marvellous thing that happened at St. Christopher's was the form of drug control. My husband and I went to the theatre two days before he died because his drugs were dosed in such a way that he never became a vegetable, and his life, even though he was consumed with the disease at the end, was always worth living. This I think is one of the biggest things against euthanasia because his life never became unbearable.

The hospital itself is architecturally a delight, which I think is also very important-and this is obviously something that Lord Aberdare ought to be thinking about. Most of our hospitals are really pretty sombre places and a lot of them should be rebuilt. The day-clinic was a joy to go to; it was like a social outing as opposed to those ghastly sessions at radiotherapy, where you are kept waiting for hours for transport and hours because the appointments have been over-booked. Believe me it is agony when somebody is undergoing radiotherapy-and all of you know the effect that has on you of total depression and vomiting and sickness-to have to go for a four-hour session for the sake of a five-minute treatment. That happens all the time. Now I do not know why-maybe it is a lack of organization, obviously it is understaffing, but it was a terrible problem. This never happened at St. Christopher's because presumably they have a large enough staff not to allow it to happen. Also I was taught with loving care to look after my husband and I think it was considered the more I could do for him the happier they were.

I must not go on about this because it is beginning to sound like a commercial for St. Christopher's and I know that Dr. Saunders and Sister McNulty are going to tell you about the professional aspects. But before they say anything $I$ just want to tell you that for me and my husband their method was $100 \%$ successful. It was a totally different experience from that with my mother. I understand that there is an increase in the numbers of people dying in hospitals. I would think that if home assistance could be better organized this would not be the case. I do think that people would prefer that those they loved died with themI certainly did. I think they needed my comfort, they needed my love-which I could not expect a detached medical person to give. But you do need help; believe me you do need help. It is the most frightening thing to be left on your own with this situation if you are not a professional. It would seem to me that it is necessary for some sort of corps to come into action as soon as somebody is pronounced incurable-a 24-hour service of G.P.s, possibly retired G.P.s who work on a shift system, so that you could have somebody to come and give injections all night long and not feel that you are putting upon them. That is just a theory obviously, it is not my place to suggest that. But I do think people would prefer it if it were made possible.

Now over the last three years $I$ have seen that death can be appalling. But $I$ do believe that in nine times out of ten that is not necessary, and I hope with all my heart that this symposium is going to be one step in the direction of allowing all of us, and I do mean us, to die with dignity.

\section{A Death in the Family: A Professional View}

\section{CICELY SAUNDERS}

I once asked a man who knew he was dying what he looked for above all in the people round him, and he paused a moment and then he said, "For someone to look as if they are trying to understand me." He did not ask for success. He asked for the effort of trying. That is why we are all here today, and we have already been brought right into the centre of the situation of the patient who is dying and his family. We are beginning to try to understand, and I think I can best continue by sharing some of the things we have been trying to understand at St. Joseph's and St. Christopher's and other places as well. Above all we try to allow our patients to speak for themselves.

So often people are just not protected from the truth that you think you are protecting them from; they are left alone with it instead. I remember sitting down with one particular patient and saying, "How are you settling in ?" He said, "I don't know if I have time. I think it's a little wooden box." He wanted to talk, and then he tucked it away again. On the record a few days later talking to one of the nurses, he said, "Of course it's just my rheumatism, I'm really not too worried."

The patient and his family are often separated by unshared knowledge. I remember one man talking with me about the 18 months after his first operation when he could not think what had happened to his marriage. There was some barrier between him and his wife, and he did not know what it was until eventually he had a recurrence and he tackled the doctors. The doctors, seeing the person, the man, behind the questions, then told him and he and his wife were able to share the trouble. And I remember asking him, "Back at the beginning, would you rather that you had been told more, or that your wife had been told less ?" He said, "The second, but whatever had happened I would have wanted to share." They did come together, and they stayed together.

\section{The Patient and His Pain}

I have been asked to talk about the patient and his pain, and I think this is very important at this stage. If we are thinking of the things that separate the patient from those around him, certainly pain can be one of them. One patient on admittance, sitting bolt upright with tension, was separated from his wife with her terrible feelings of inadequacy as if by a solid wall. Home had become impossible just because of pain. By relieving that pain, we were able to bring them together, so that they were more together after he was admitted than they were when they were alone at home. More outpatient facilities so that this could happen at home are, I think, one of the most important developments just beginning in terminal care at the moment. For some patients, however, pain is something that is so all-embracing that it really cannot be coped with adequately all the time at home. Chronic pain is an apparently endless situation, whose meaning is really only one of threat One patient 